\title{
O ESTADO DEMOCRÁTICO DE DIREITO COMO PRINCÍPIO CONSTITUCIONAL ESTRUTURANTE DO DIREITO ADMINISTRATIVO: UMA ANÁLISE A PARTIR DO PARADIGMA EMERGENTE DA ADMINISTRAÇÃO PÚBLICA DEMOCRÁTICA
}

José Sérgio da Silva Cristóvam ${ }^{1}$

\section{RESUMO}

O presente ensaio aborda o tema do Estado democrático de direito como princípio constitucional estruturante do Direito Administrativo, a partir da construção de um renovado regime jurídico administrativo, com a travessia de um modelo mais autoritário, imperativo e autocrático de Administração Pública (paradigma tradicional), para uma perspectiva mais consensual, dialógica, isonômica, democrática e de construção plural das decisões administrativas (paradigma da Administração Pública democrática).

Palavras-chave: Estado democrático de direito. Princípios constitucionais estruturantes. Regime jurídico-administrativo. Paradigma emergente. Administração Pública democrática.

\section{THE DEMOCRATIC STATE OF LAW AS A STRUCTURAL CONSTITUTIONAL PRINCIPLE OF ADMINISTRATIVE LAW: AN ANALYSIS FROM THE EMERGING PARADIGM OF DEMOCRATIC PUBLIC ADMINISTRATION}

\begin{abstract}
This paper discusses the theme of the democratic state of law as a structural constitutional principle of Administrative Law, from the construction of a new legal administrative system, with the crossing of a more authoritarian model, and autocratic imperative of Public Administration (traditional paradigm) for a more consensual perspective, dialogic, isonomic, democratic and plural construction of administrative decisions (paradigm of Public Administration democratic).

\footnotetext{
${ }^{1}$ Mestre e Doutor em Direito pela Universidade Federal de Santa Catarina - UFSC, Santa Catarina, (Brasil). Com estágio de Doutoramento Sanduíche na Universidade de Lisboa (Portugal). Professor Adjunto de Direito Administrativo do CCJ/UFSC. Conselheiro Estadual da OAB/SC.

E-mail: jscristovam@gmail.com
} 
Keywords: Democratic state of law. Structural constitutional principles. Legal administrative system. Emerging paradigm. Public Administration democratic.

\section{INTRODUÇÃO}

O desabrochar do novo milênio trouxe consigo a pretensão de consolidação do fenômeno da constitucionalização do Direito, já ensaiado desde o Segundo Pós-Guerra, com profundos reflexos na metodologia constitucional contemporânea, inclusive com destacada colonização da dogmática jurídico-administrativa, a partir da edificação de um sofisticado e abrangente sistema constitucional administrativo. A disciplina administrativa atual não pode prescindir de uma concepção umbilicalmente vinculada à matriz constitucional, o conjunto de normas constitucionais que conformam o atual regime jurídico-administrativo. ${ }^{2}$

Essa é a tônica central da temática aqui debatida, a partir da construção de uma adequada e sistematizada concepção de regime jurídico-administrativo, constitucionalmente vinculado como estrutura normativa e conjunto de finalidades e objetivos, a ser acompanhada pela construção normativo-axiológica das suas linhas mestras (princípios estruturantes).

O estudo tem justificativa a partir da proposta de superação (total ou parcial) daquele paradigma tradicional, que fundava e legitimava o regime jurídico administrativo no princípio da supremacia do interesse público, do que decorria o assimétrico e verticalizado sistema de poderes e prerrogativas da Administração Pública, com a reconstrução das suas bases de justificação e conformação sistemática, agora sobre fundamentos estruturantes capazes de afinar o diálogo e manter uma dialética de legitimidade sinfônica com todo o arranjo normativo constitucional, sob a batuta instrumental e horizontalizante do Estado constitucional de direito e do paradigma emergente da Administração Pública democrática. ${ }^{3}$

\footnotetext{
${ }^{2}$ Sobre o fenômeno da constitucionalização do Direito Administrativo, consultar: BARROSO, Luís Roberto. A constitucionalização do direito e suas repercussões no âmbito administrativo. In: ARAGÃO, Alexandre dos Santos; MARQUES NETO, Floriano de Azevedo (Coord.). Direito Administrativo e seus novos paradigmas. Belo Horizonte: Fórum, 2008, p. 31-63; CRISTÓVAM, José Sérgio da Silva. Administração Pública democrática e supremacia do interesse público: novo regime jurídico-administrativo e seus princípios constitucionais estruturantes. Curitiba: Juruá, 2015, p. 217-227.

${ }^{3}$ Sobre o debate relacionado à superação do paradigma tradicional da supremacia do interesse público, bem como a construção do novo regime jurídico-administrativo comum ao paradigma da Administração Pública
} 
O problema fulcral a ser debatido pode ser assim alinhado: há base teórica e normativo-constitucional para a edificação de um novo paradigma para o Direito Administrativo (paradigma emergente da Administração Pública democrática), a partir dos princípios estruturantes da dignidade da pessoa humana, do Estado democrático de direito e do princípio republicano?

Como hipótese básica do presente ensaio, entende-se que a referida trinca de princípios estruturantes não servem como parâmetros normativos que possam isoladamente sustentar o regime jurídico-administrativo, mas sim como verdadeira trindade principiológica estruturante assecuratória dos padrões de unidade interior e adequação valorativa conformadores de todo o edifício constitucional administrativo.

Com efeito, eis os objetivos centrais do estudo: a partir de uma leitura sistemática e comprometida com a plena efetividade das normas constitucionais, busca-se oferecer as bases para um novo regime jurídico-administrativo, submetido a um verdadeiro "choque de constitucionalização", que resplandece renovado e reestilizado em seus conceitos e nos contornos dos institutos tradicionais. Não por qualquer irresponsável ou pouco ilustrada doutrina de simples abandono daquele modelo tradicional, mas por uma profunda e radical revisão da sua lógica conceitual e dos seus limites operacionais e normativos.

Sobre a noção de princípios estruturantes, aqui recorrentemente referida, parte-se da doutrina do constitucionalista lusitano José Joaquim Gomes CANOTILHO, que os define como aquelas "traves-mestras jurídico-constitucionais do estatuto jurídico do político", as diretrizes normativas fundamentais, constitutivas e indicativas "das ideias directivas básicas de toda a ordem constitucional". Assim concebidos, os princípios estruturantes acabam por alcançar concretização pela via de outros princípios e regras constitucionais de densificação, que iluminam "o seu sentido jurídico-constitucional e político-constitucional, formando, ao mesmo tempo, com eles, um sistema interno" (CANOTILHO, 2003, p. 1173-1174).

O debate sobre o Estado democrático de direito, como princípio estruturante desse novo regime jurídico administrativo, funda-se nesse novo paradigma emergente da Administração Pública democrática, aqui enfatizados os contornos da participação social na formação das decisões administrativas e da eficiência na gestão da máquina pública.

democrática, a partir dos princípios constitucionais estruturantes da dignidade da pessoa humana, do Estado democrático de direito e do princípio republicano, consultar: CRISTÓVAM, José Sérgio da Silva. Administração Pública democrática e supremacia do interesse público: novo regime jurídico-administrativo e seus princípios constitucionais estruturantes. Curitiba: Juruá, 2015, p. 121-318. 


\section{O ESTADO DEMOCRÁTICO DE DIREITO COMO PRINCÍPIO CONSTITUCIONAL ESTRUTURANTE}

A vigorosa inflação do debate sobre a constitucionalização do Direito Administrativo alcança o diálogo em torno do Estado democrático de direito e dos modelos de democracia, o que tem povoado o cenário teórico e político da metodologia constitucional contemporânea. ${ }^{4}$ De fato, são diversas as teorias democráticas ${ }^{5}$ que procuram explicar a complexidade do contexto sociopolítico da atualidade, fato a desencorajar e mesmo desaconselhar, para os estreitos limites desse trabalho, qualquer abordagem crítica com pretensões de sistematicidade e completude, nem uma recuperação da construção histórica da democracia, ${ }^{6}$ cabendo apenas aportes teóricos preliminares, necessários ao debate sobre o regime jurídico-administrativo.

O estudo do Estado democrático de direito e do princípio democrático, sob a perspectiva do constitucionalismo brasileiro, não permite suprimir um necessário componente ideológico-constitucional, a sua veia genética de instrumento de luta e de compromisso com a transformação social. Tanto que, no seu manifesto pela democracia participativa, o constitucionalista Paulo BONAVIDES a coloca, juntamente com o Estado social, como os “axiomas que hão de permanecer invioláveis e invulneráveis, se os povos continentais da América Latina estiverem no decidido propósito de batalhar por um futuro que reside tãosomente na democracia, na liberdade do desenvolvimento". E, ainda, alerta para o problema da escravização da mídia pelo capital, um dos maiores inimigos da democracia participativa, quando denuncia que, dispondo da "máquina da informação com que intentam dar aparência

\footnotetext{
${ }^{4}$ Sobre o modelo de Estado democrático de direito e democracia na contemporaneidade, consultar: BOBBIO, Norberto. O futuro da democracia: uma defesa das regras do jogo. Tradução de Marco Aurélio Nogueira. Rio de Janeiro: Paz e Terra, 1986; CANOTILHO, José Joaquim Gomes. Direito Constitucional e teoria da Constituição. 7. ed. Coimbra: Almedina, 2003, p. 243-281; GARCIA DE ENTERRIA, Eduardo. Democracia, jueces y control de la Administración. 4. ed. Madrid: Civitas, 1998, p. 31-163; MIRANDA, Jorge. Manual de Direito Constitucional: direitos fundamentais. t. IV. 5. ed. Coimbra: Coimbra Editora, 2012, p. 239-256; TAVARES, André Ramos; BUCK, Pedro. Direitos fundamentais e democracia: complementaridade/contrariedade. In: CLÈVE, Clèmerson Merlin; SARLET, Ingo Wolfgang; PAGLIARINI, Alexandre Coutinho (Org.). Direitos humanos e democracia. Rio de Janeiro: Forense, 2007, p. 169-186.

5 Sobre as teorias modernas da democracia, consultar: BONAVIDES, Paulo. Teoria constitucional da democracia participativa: por um Direito Constitucional de luta e resistência, por uma nova hermenêutica, por uma repolitização da legitimidade. 2. ed. São Paulo: Malheiros, 2003, p. 09-66; CANOTILHO, José Joaquim Gomes. Direito Constitucional e teoria da Constituição. 7. ed. Coimbra: Almedina, 2003, p. 1409-1421; HABERMAS, Jürgen. Direito e democracia: entre facticidade e validade. Tradução de Flávio Beno Siebeneichler. v. I e II. Rio de janeiro: Tempo Brasileiro, 1997.

${ }^{6}$ Sobre a recuperação histórica da democracia, desde a Antiguidade clássica, consultar: DAHL, Robert A. Sobre a democracia. Brasília: UnB, 2001, p. 17-36.
} 
de legitimidade aos seus interesses, os estamentos de dominação têm tudo com que perpetuar a servidão social e o confisco dos direitos de expressão" (BONAVIDES, 2003, p. 09-13).

Com efeito, a construção de um efetivo e substancial Estado social e democrático de direito, não apenas formal, exige a ruptura com as práticas de exclusão e marginalização características dos modelos extremados de neoliberalismo e globalização econômica, verdadeiros entraves à democracia material. É necessário pensar os movimentos de abertura globalizante, com pretensões de construção de outro modelo de globalização, não aquela globalização perversa do pensamento único, monolítico e colonizador, mas uma globalização de travessia para uma consciência universal de respeito às diferenças e à dignidade humana. Uma utopia possível onde as tecnologias não sirvam para escravizar as pessoas e alimentar o mercado voraz, mas que sejam instrumentos libertários e emancipatórios do ser humano. ${ }^{7}$

Lançadas essas escassas luzes sobre essa perspectiva mais política e sociológica do que propriamente jurídico-normativa, passa-se à breve análise das principais teorias da democracia na contemporaneidade, preparando o terreno teórico para o debate acerca do Estado democrático de direito e seu conteúdo normativo-constitucional.

\section{ALGUMAS TEORIAS DA DEMOCRACIA: BREVES PINCELADAS SOBRE UM QUADRO EM CONSTANTE CONSTRUÇÃO}

$\mathrm{Na}$ apresentação das diferentes teorias da democracia, CANOTILHO (2003) usa de uma didática menção aos seguintes modelos e concepções teóricas: a teoria democráticopluralista; a teoria elitista da democracia; a teoria da democracia do "ordo-liberalismo"; a teoria normativa da democracia liberal; a teoria normativa da democracia republicana; a teoria normativa da democracia deliberativa; a teoria normativa da democracia discursiva; a teoria normativa da democracia corporatista; a concepção minimalista de democracia; e, a democracia eletrônica.

Dentre os referidos modelos pode-se brevemente destacar a "teoria pluralista da democracia”, que tem um caráter ao mesmo tempo empírico e normativo. Para as teorias pluralistas o processo de formação da vontade democrática não reside nem no povo dos sistemas plebiscitários nem em uma noção de indivíduo abstrato (teoria liberal), mas em grupos decorrentes da frequência de interações sociais, sendo que as decisões estatais 
representariam os inputs veiculadores dos interesses desses grupos. As decisões políticas seriam o reflexo e a resposta a esses interesses de grupos sociais (CANOTILHO, 2003, p. 1409).

Ainda que sejam possíveis diversas críticas ao modelo pluralista, em especial uma objeção realista de que os diferentes grupos de interesses não dispõem de iguais oportunidades de influência política, o constitucionalista lusitano ressalta que, sob uma perspectiva normativa, o pluralismo representa mais do que uma dimensão do princípio democrático, sendo mesmo um elemento constitutivo da ordem constitucional. Nesta esteira, as forças sociais e os grupos coletivos ostentariam uma "capacidade de transformação qualitativa das relações humanas" (CANOTILHO, 2003, p. 1411).

Outra categoria referida é a "teoria elitista da democracia", que parte de um conceito (até certo ponto realista) de democracia como método de obtenção do apoio do povo pela concorrência, uma forma de dominação fundada na concorrência para o exercício do poder, quando os governados decidem, pelo voto, "qual a elite concorrente que deveria exercer o poder" (CANOTILHO, 2003, p. 1411-1412).

Embora possam ser estabelecidos limites formais à escolha das políticas pelas elites governantes, não se pode negar que a teoria elitista apresenta uma profunda contraposição a qualquer modelo de participação popular ativa na determinação das decisões políticas. Inclusive, isto colide diretamente como os preceitos normativos do modelo de Estado social e democrático de direito estruturado pelo sistema constitucional brasileiro, fundado em um conjunto de princípios e direitos fundamentais (individuais e sociais), entre os quais a efetiva participação popular no diálogo político nacional e na formação das decisões que conformam o espírito político da comunidade.

Merece destaque, também, a "teoria normativa da democracia republicana", que vê na política uma "dimensão constitutiva da vontade democrática", pelo que a democracia se converte em um "compromisso ético-político" com uma identidade coletiva da comunidade, uma "forma de reflexão do bem comum", a "auto-organização política da comunidade no seu conjunto". Diversamente da sua opositora "teoria normativa da democracia liberal", ${ }^{8}$ fundada em uma teoria forte dos direitos e em uma desconfiança acerca da racionalidade da política, a

\footnotetext{
${ }^{7}$ A concepção deste "outro modelo de globalização" é buscada na obra do sociólogo brasileiro Milton SANTOS. Sobre o tema, consultar: SANTOS, Milton. Por uma outra globalização: do pensamento único à consciência universal. 5. ed. Rio de Janeiro: Record, 2001.
} 
concepção republicana entende o cidadão não somente como um sujeito de direitos e liberdades negativas, mas também (sobretudo) como um sujeito de direitos de participação e comunicação política (liberdades positivas) (CANOTILHO, 2003, p. 1414-1416).

$\mathrm{O}$ avançar nessa rápida e incompleta visão geral leva a dois dos mais influentes modelos teóricos de democracia na atualidade, as chamadas concepções de democracia deliberativa e discursiva, que têm em Jürgen HABERMAS o seu grande expoente filosófico. A diferir os dois modelos, em linhas gerais, está o fato de que a democracia discursiva não se assenta em direitos universais do homem nem na moral social de uma determinada comunidade, como ocorre em maior medida no modelo da democracia deliberativa (republicanismo-liberal). ${ }^{9}$ A concepção discursiva de democracia está fundada em "regras de discussão, formas de argumentar, institucionalização de processos - rede de discussão e negociação - cujo fim é proporcionar uma solução nacional e universal a questões problemáticas, morais e éticas da sociedade". Trata-se de um conceito procedimental de democracia, um processo de auto-organização política da sociedade, um modelo de democracia distanciada de concepções estatais e preocupada com a construção de "uma rede de comunicação e participação estruturante de uma sociedade democrática" (CANOTILHO, 2003, p. 1416-1417).

No modelo habermasiano de democracia discursiva são centrais os conceitos de esfera pública e sociedade civil. A noção de esfera pública é caracterizada pela participação igualitária e pública de um sujeito plural, quando os problemas são debatidos pela via de um processo comunicativo onde prevalece a autoridade do melhor argumento. Um espaço marcado pela constante ampliação do domínio público, com a incorporação de novos problemas e questões submetidas ao debate racional. Para HABERMAS, a "esfera pública pode ser descrita como uma rede adequada para a comunicação de conteúdos, tomadas de posição e opiniões; nela os fluxos comunicacionais são filtrados e sintetizados, a ponto de se condensarem em opiniões públicas enfeixadas em temas específicos" (HABERMAS, 1997, p. 92).

A noção habermasiana de sociedade civil revela-se como um espaço relevante na construção da ideia de esfera pública democrática, porquanto diretamente relacionada ao mundo da vida, o que assegura a proximidade com os problemas e questões do cidadão

\footnotetext{
${ }^{8}$ Sobre o modelo de democracia liberal, consultar: CUNNINGHAM, Frank. Teorias da democracia: uma introdução crítica. Tradução de Delamar José Volpato Dutra. Porto Alegre: Artmed, 2009, p. 38-90.
} 
comum, sem uma elevada contaminação pela dinâmica instrumental (HABERMAS, 1997, p. 99).

Uma crítica que pode ser dirigida ao modelo habermasiano de democracia procedimental-discursiva refere-se à necessidade de condições de igualdade de oportunidade e de participação livre e instruída no debate público, que estão muito distantes da realidade de democracias periféricas, como a brasileira. O deficit de educação política e de maturidade democrática da comunidade nacional faz com que, para além das teorias, esse tipo de proposta de democracia discursiva acabe por representar uma espécie de ideal distante.

Outro modelo de democracia, com claras disposições políticas e axiológicas, pode ser buscado na proposta bonavidiana de democracia participativa, que parte de uma concepção amplamente fundada no modelo de Estado constitucional de direito. Segundo BONAVIDES (2003), este modelo representaria para os países de periferia a versão mais acabada e insubstituível do Estado social. Com base em uma análise bastante realista do debate institucional brasileiro, sustenta que a escravização do Legislativo pelo Executivo coloca os juízes e os tribunais em uma posição de autênticos defensores da ordem constitucional, cuja função é fortalecer a supremacia dos valores e princípios do Estado constitucional de direito.

A partir de um modelo de discurso comprometido com a Constituição, o constitucionalista pátrio alerta que, em países em desenvolvimento como o Brasil, escravizados pelo capital transnacional globalizante, não há senão uma ditadura dissimulada em democracia representativa, onde, de resto, nem se sabe quem é e onde está o povo. Por isso, a democracia participativa pressupõe a superação da clássica noção de separação de poderes, avançando para uma divisão funcional e orgânica de poderes, fundada no princípio da unidade da Constituição, um constitucionalismo de luta e resistência, expressão ideológica da democracia participativa (BONAVIDES, 2003, p. 26-30).

Depois de atestar o papel nefasto que os meios de comunicação (mídia) têm desempenhado na construção de uma democracia real, responsáveis em larga medida pela passividade do povo (apatia política), BONAVIDES denuncia que a "mídia, nas mãos da classe dominante, é a mais irresistível força de sustentação do status quo e de seus governos conservadores, impopulares, injustos" (BONAVIDES, 2003, p. 47).

\footnotetext{
${ }^{9}$ Sobre o modelo de democracia deliberativa, consultar: SILVA, Felipe Gonçalves. Iris Young, Nancy Fraser e Seyla Benhabib: uma disputa entre modelos críticos. In: NOBRE, Marcos (Org.). Curso livre de teoria crítica. Campinas: Papirus, 2008, p. 199-226.
} 
Com efeito, pode-se dizer que no Brasil há um espírito democrático bloqueado por um modelo de representatividade profundamente deslegitimado, inclusive pela crise de representatividade dos partidos políticos, ${ }^{10}$ uma democracia mutilada, sem a sua essência constitutiva (o povo). Mas é necessário ressaltar que a proposta de democracia participativa não pretende a supressão da esfera de representação política. Aposta sim no fortalecimento e na efetivação de uma esfera direta de participação popular, um modelo comprometido com a eficácia e efetividade dos direitos fundamentais, capaz de tornar viável aquela utopia emancipatória e libertária da Constituição Cidadã.

Ainda que instigante e sofisticada, uma proposta de democracia participativa assim concebida engendra algumas objeções. As grandes críticas conceituais e normativas a esta proposta político-ideológica de democracia participativa são aquelas comuns ao próprio neoconstitucionalismo, do qual retira seus principais elementos teóricos. Pode-se ressaltar, em especial, o seu inegável deficit democrático intrínseco, na medida em que o modelo reconhece no ativismo judicial um dos seus traços constitutivos, fenômeno que, a médio e longo prazo, pode resultar, inclusive, no acirramento daquele quadro de apatia política que se pretendia superar.

No intento de fortalecer a participação popular, ainda que pela via do ativismo judicial, pode-se estar fomentando muito mais a figura do cidadão-cliente do sistema judicial do que o cidadão-participante (democracia participativa e cidadania ativa). Esta é sempre uma situação arriscada, porque submetida aos imponderáveis típicos dos fenômenos sociais e políticos, insuscetíveis de quaisquer previsões mais certeiras, como são atualmente os fenômenos meteorológicos.

Por outro lado, não se pode negar a fecunda semente emancipatória e libertária dessa proposta axiológica de democracia participativa. Mesmo se considerada a partir da sua firme crença no ativismo judicial, parece forçoso reconhecer que, em uma comunidade política alimentada por uma democracia ainda infante, a busca judicial pelos direitos já é um relevante elemento de educação cívica e formação cidadã para a democracia. Por certo, não se deve deixar cegar e seduzir irracional e ilimitadamente pelo "belo canto da sereia" do ativismo judicial, mas ignorar solenemente esse fenômeno, fechando os ouvidos com cera como fez o Ulisses mitológico, também não parece uma postura adequada para a construção do projeto de cidadania ativa e democracia participativa.

\footnotetext{
${ }^{10}$ Sobre a problemática da crise de representatividade do modelo democrático e do sistema de partidos no Brasil, consultar: MEZZAROBA, Orides. A reforma política e a crise de representatividade do sistema partidário
} 
A luta pelo reconhecimento dos direitos, mesmo que pela via judicial, já planta no coração do indivíduo uma semente de cidadania ativa e participativa, põe na sua boca o doce gosto da perspectiva democrática, pelo que não parecem inconciliáveis o ativismo judicial de densificação dos direitos fundamentais e o modelo de democracia participativa. Esta não pode se esgotar naquele, mas aquele lhe serve de destacado e imediato combustível propulsor. ${ }^{11}$

A democracia é o alimento espiritual para a alma política da comunidade, exigindo liberdade e igualdade, valores que não podem ser atingidos sem educação e formação cidadã. Para receber em plenitude o alimento espiritual democrático, a comunidade política deve estar preparada, já confessada e exorcizada dos seus mais terríveis pecados de desigualdade social e de desapego a uma ética humanista (respeito aos direitos humanos fundamentais). Não é possível conceber a ideia de um povo que luta por seus direitos e cumpre com os seus deveres, se nem mesmo sabe que os têm e nem se sente parte desse corpo político-social. Seria como tentar "convencer racionalmente" um peixe de que ele é uma ave, levá-lo a lugar alto qualquer e lançá-lo aos céus, dizendo: voa passarinho!

A formação política pressupõe educação para a cidadania e liberdade de informação, o povo deve ser constituído e respeitado como cidadão (sentimento de cidadania). Não se pode cogitar de um efetivo diálogo democrático (democracia discursiva), se grande parte do respectivo auditório (esfera pública) não dispõe de condições mínimas para a participação livre e instruída (elevados índices de analfabetismo formal e funcional). A verdade é que a história política de uma nação raramente se constrói com saltos (como aquele do "peixe passarinho"), a caminhada ocorre quase sempre a passos lentos.

Em suma, a proposta axiológica de democracia participativa representa um estágio na progressiva evolução para uma dimensão de democracia discursiva, naquele modelo habermasiano de procedimento dialógico aberto e plural, com igualdade de condições para a participação livre e instruída de todos os membros da esfera pública, em que os mais variados assuntos podem ser trazidos ao debate. No Brasil, este é ainda um projeto futurista, uma

\footnotetext{
brasileiro. Sequência: Estudos Jurídicos e Políticos, Florianópolis, v. 27, n. 53, p. 95-112, dez. 2006.

${ }^{11}$ Em sentido semelhante, sobre a compatibilidade entre o discurso democrático e o ativismo judicial, consultar: BORGE, Felipe Dezorzi. Ativismo jurídico: expressão do acesso à Justiça e da cidadania ativa. Jus Navigandi, Teresina, ano 14, n. 2317, nov. 2009. Disponível em: 〈http://jus.com.br/artigos/13794〉. Acesso em: 08 set. 2016; GARAPON, Antoine. O Juiz e a Democracia: o guardião de promessas. Tradução de Maria Luiza de Carvalho. 2. ed. Rio de Janeiro: Revan, 1999; LEITE, Gisele. Considerações sobre ativismo judicial, constitucionalismo e democracia. Jus Navigandi, Teresina, ano 19, jan. 2014. Disponível em: <http://jus.com.br/artigos/26337>. Acesso em: 08 set. 2016.
} 
utopia a ser construída pela via libertária da educação e da formação política e cidadã da nação.

Ainda que o país tenha sido recentemente sacudido por uma importante onda de manifestações populares (jornadas de junho/2013), com sólidas pautas reivindicatórias de melhor qualidade nos serviços públicos de transporte coletivo, saúde e educação, bem como duras críticas aos poderes constituídos e à epidemia de corrupção instalada em todas as esferas e estruturas de poder, em especial o Legislativo e o Executivo, não parece que isso possa ser catalogado como um passo decisivo de ruptura com a apatia política tupiniquim que reinou nas últimas décadas. Mas é, sem dúvida, um sinal a ser considerado. Uma das fragilidades desses movimentos parece habitar na sua rarefeita organização (informação e formação política), o que os torna presas fáceis para hábeis mãos manipuladoras de seguimentos da mídia ou de outros grupos de interesses, que podem tanto facilmente dispersálos como também canalizá-los para outras conveniências de ocasião.

\section{O ESTADO DEMOCRÁTICO DE DIREITO COMO PRINCÍPIO FUNDAMENTAL}

Ao iniciar a apresentação da democracia como princípio normativo, CANOTILHO (2003) recorre àquela difundida formulação essencial de Abraham LINCOLN sobre a democracia, como o "governo do povo, pelo povo e para o povo". Esta seria a "síntese mais lapidar dos momentos fundamentais do princípio democrático", um verdadeiro "modo de justificação positiva da democracia", que ele chama de "fórmula de Lincoln".

Em sentido semelhante, BONAVIDES (2003) sustenta que o povo é o sujeito ativo do processo democrático, pelo que não há democracia sem participação, o que pode haver é uma ditadura constitucional. O povo é o pressuposto fundamental de todo o sistema democrático de poder. Nesta quadra, apresenta a noção de "povo" em três dimensões: povo no sentido político (ligado à noção de participação popular); povo no sentido jurídico (cidadania vinculada à determinada ordem jurídica); e povo no sentido sociológico (laços étnicos e culturais que formam a consciência nacional, povo como nação).

Mas antes de discutir o Estado democrático como princípio axiológico normativo fundamental da ordem constitucional brasileira, interessa abrir um breve parêntese para fazer menção ao próprio conteúdo normativo do Estado de direito, como ordem constitucional de natureza constitutiva, material, procedimental e formal, "que visa dar resposta ao problema do conteúdo, extensão e modo de proceder da actvidade do estado", no sentido de "conformar as 
estruturas do poder político e a organização da sociedade segundo a medida do direito", um "meio de ordenação racional e vinculativa de uma comunidade organizada", conformado a partir do estabelecimento de regras e medidas, da prescrição de formas e procedimentos, e da criação de instituições (CANOTILHO, 2003, p. 243).

No sistema constitucional brasileiro o Estado de direito está umbilicalmente vinculado à concepção de Estado constitucional de direito, a partir de um complexo normativo que se espraia por quase toda a Constituição Federal, podendo ser identificado, dentre outras disposições, na organização da forma federativa de Estado (artigo $1^{\circ}$, caput e artigos 18 a 33), na separação de poderes e distribuição de funções (artigo $2^{\circ}$ e artigos 44 a 126), na carta de direitos individuais, coletivos, sociais e políticos (em especial nos artigos $5^{\circ}$ a 17), no processo legislativo (artigos 59 a 69), no controle de constitucionalidade (artigos 102 e 103) e nas prescrições que regem a Administração Pública (artigos 37 a 41).

Retomando a questão do Estado democrático de direito e seu status constitucional, cabe lembrar que o próprio preâmbulo da Constituição Federal já faz expressa menção ao "Estado democrático", ao passo que o artigo 1º, caput refere-se ao "Estado democrático de direito". Outras Constituições trazem expressões semelhantes: a Lei Fundamental alemã de 1949 refere-se ao "Estado de direito republicano, democrático e social" (artigo 28); a Constituição portuguesa de 1976 somente mencionava a expressão "Estado de Direito democrático" em seu preâmbulo, sendo que, com a Revisão Constitucional de 1982, a formulação passou também para o articulado constitucional (artigos $2^{\circ}$ e $9^{\circ}$, "b"); a Constituição espanhola de 1978 refere-se ao "Estado social e democrático de direito" (artigo $\left.1^{\mathrm{o}}\right) .^{12}$

Certamente, nada obstante a sintética expressão enunciativa, a Constituição Federal impõe ao Estado brasileiro um modelo de Estado republicano, social e democrático de direito, em todas as suas dimensões substanciais (materiais) e procedimentais (organizacionais). Vincula a legitimação do próprio Estado ao cumprimento de uma série de obrigações negativas (direitos de liberdade) e prestacionais (direitos sociais), os princípios relacionados à soberania popular, ao pluralismo, à cidadania e à participação política democrática, bem como impõe o cumprimento de diversas regras procedimentais para o exercício legítimo do poder.

12 Para uma análise comparativa em diversas outras ordens constitucionais, consultar: MIRANDA, Jorge. Manual de Direito Constitucional: direitos fundamentais. t. IV. 5. ed. Coimbra: Coimbra Editora, 2012, p. 250. 
Nesse sentido, CANOTILHO sustenta a democracia como um princípio jurídicoconstitucional com dimensões materiais e organizativo-procedimentais, um princípio complexo forjado a partir das várias dimensões das próprias concepções de democracia. Em uma dimensão representativa, "o princípio democrático acolhe os mais importantes postulados da teoria democrática representativa - órgãos representativos, eleições periódicas, pluralismo partidário, separação de poderes”. Já a partir de uma dimensão participativa, o princípio democrático implica a "estruturação de processos que ofereçam aos cidadãos efectivas possibilidades de aprender a democracia, participar nos processos de decisão, exercer controlo crítico na divergência de opiniões, produzir inputs políticos democráticos" (CANOTILHO, 2003, p. 287-288).

Estas duas dimensões do princípio democrático estão largamente concretizadas no sistema constitucional brasileiro. O modelo de democracia representativa pode ser extraído do próprio artigo $1^{\circ}$, parágrafo único da Constituição Federal, quando enuncia que "todo o poder emana do povo, que o exerce por meio de representantes eleitos ou diretamente, nos termos desta Constituição”. Há, ainda, para exemplificar, as normas que regulam os órgãos representativos da Câmara dos Deputados e do Senado Federal (artigos 44 a 58); que preveem o pluralismo político ${ }^{13}$ como princípio fundamental (artigo $1^{\circ}, \mathrm{V}$ ); que dispõem sobre o sufrágio universal, o voto direto, secreto e periódico (artigos 14, caput e 60, § 4 , II); que regulam os partidos políticos (artigo 17).

A perspectiva da democracia direta e participativa também está prevista, tanto no artigo $1^{\circ}$, parágrafo único da Constituição Federal, com no artigo 14, I, II e III (plebiscito, referendo e iniciativa popular de leis), além de todas as disposições constitucionais que asseguram a liberdade de expressão, o direito de reunião e de manifestação política (artigo $5^{\circ}$, VIII, IX e XVI), bem como a participação dos cidadãos na fiscalização das atividades estatais e na formação das decisões políticas, conforme restará discutido logo abaixo.

Em suma, pode-se entender o princípio democrático como um modelo dinâmico, em constante transformação, avesso a qualquer reducionismo ou aprisionamento estático em um conceito normativo ou político fechado. É princípio aberto e informador de todas as ações estatais e da sociedade, a apontar o caminho do contínuo processo de democratização do espaço público, a partir de um modelo de educação para a cidadania e do desenvolvimento

\footnotetext{
${ }^{13}$ Sobre o tema do pluralismo político no Brasil, consultar: NASPOLINI, Samuel Dal-Farra. Pluralismo político: subsídios para análise dos sistemas político e eleitoral brasileiros em face da CF/88. Curitiba: Juruá, 2006.
} 
livre de todas as pessoas (autodeterminação), com vistas à efetiva participação crítica no processo político, em igualdade de condições intelectuais, sociais, políticas e econômicas.

Não restam dúvidas, portanto, que o princípio democrático e que a dimensão substancial e procedimental do Estado democrático de direito apontam na direção dos postulados da justiça material e da igualdade substancial, a funcionar não só como limites e fatores de legitimação formal à ação estatal, mas também (e sobretudo) como mecanismos de defesa e promoção dos direitos fundamentais (individuais e sociais). Uma relação dialética que não se esgota no relevante papel de defesa da liberdade de participação (liberdade de expressão, de manifestação, de reunião, de associação), atingindo também aqueles contornos prestacionais imprescindíveis à efetiva participação livre, na trilha da construção de uma democracia educacional, cultural, social e econômica.

Com efeito, não há genuína liberdade democrática sem igualdade material, sem as condições mínimas de participação ativa e crítica na vida pública. Na raiz constitutiva do Estado democrático de direito estão os direitos fundamentais individuais e sociais, em uma genética indissociável, que funda o próprio modelo de Estado constitucional de direito. Fora dessa dialética dos direitos fundamentais sempre haverá condições para o debate político acerca da democracia brasileira, mas não com sérias pretensões substantivas de legitimidade constitucional.

\section{ESTAdO DEMOCRÁtico DE DIREITO, ADMINISTRAÇÃo PÚBLICA DEMOCRÁTICA, CONTROLE SOCIAL E EFICIÊNCIA ADMINISTRATIVA: ALGUMAS CONSIDERAÇÕES}

Umas das mais sensíveis transformações na dinâmica da disciplina jurídicoadministrativa, a partir do vetor normativo estruturante do Estado democrático de direito, refere-se à sistemática do controle da Administração Pública, com a construção e ampliação de inúmeros canais diretamente vinculados ao que CANOTILHO (2003) definiu como a “democratização da democracia", a democracia participativa como um princípio informador do Estado e da sociedade, o que faz surgir os primeiros sinais de construção de uma autêntica Administração Pública democrática ou a democratização da Administração.

Sobre o controle da Administração Pública, importa considerar que a sistemática tradicional não reserva maior destaque ao fenômeno da participação popular (controle social), 
no controle dos atos administrativos e na formação das decisões políticas da Administração. ${ }^{14}$ Inclusive, a própria doutrina jusadministrativista, em especial aquela dos manuais, não dispensa uma preocupação mais aguda em relação ao controle popular (democracia participativa), limitando-se a esquematizar e difundir aquela estrutura básica dos sistemas de controle interno (de mérito e de legalidade), a cargo de cada entidade administrativa, e do controle externo (de legalidade em sentido estrito e de legitimidade/juridicidade), com destaque para o Poder Legislativo, com o auxílio dos Tribunais de Contas, o Poder Judiciário (ações típicas ou ações de rito ordinário) e o Ministério Público (em especial via termos de ajustamento de conduta).

Por outro lado, já passadas quase três décadas desde o advento da nova ordem constitucional brasileira, quando foram estabelecidos os contornos desse atual sistema institucionalizado de controle interno e externo do Poder Público, podem ser levantadas críticas consistentes no que concerne aos seus níveis de eficiência e efetividade no controle do agir administrativo. Ademais, não há como desconsiderar os elevados custos de manutenção de um sistema assim hipertrofiado de órgãos e agentes públicos, com diversas sobreposições de esferas de controle, modelo que se tem revelado a um só tempo dispendioso, lento e pouco proativo, ainda muito mais fundado em uma pedagogia punitiva do que na medida da orientação e do controle finalístico e de resultados.

Estas críticas ao modelo tradicional de controle administrativo reforçam a necessidade de uma maior atenção à previsão de diversos espaços e mecanismos de controle social, com a participação democrática da sociedade na fiscalização da gestão pública e no controle da atividade administrativa, que povoa em larga medida a ordem constitucional, dentre os quais podem ser destacados: 1. Direito à informação e petição aos órgãos públicos (artigos $5^{\circ}$, XXXIII e XXXIV; 31, § $3^{\circ}$ e 162 da CF/88); 2. Direito à provocação judicial do controle dos atos administrativos via mandado de segurança, mandado de injunção, habeas-data e ação popular (artigo 5 , LXIX, LXXI, LXXII e LXXIII da CF/88); 3. Direito de participação nos colegiados de órgãos públicos relativos aos respectivos interesses profissionais ou previdenciários (artigo 10 da $\mathrm{CF} / 88$ ); 4. Direito de participação do usuário de serviços públicos na Administração Pública direta e indireta (artigo 37, $\S 3^{\circ}$ da $\mathrm{CF} / 88$ ); 5. Direito à provocação do controle externo, pela via dos Tribunais de Contas, em face de irregularidades

\footnotetext{
${ }^{14}$ Sobre os novos paradigmas do controle da Administração Pública, consultar: FIALHO, Andrea Cristina de Souza. A reforma do Estado e os novos paradigmas do controle da Administração Pública. In: SILVA, Maria Teresinha Pereira; ZANOTELLI, Maurício (Coord.). Direito e Administração Pública: por uma hermenêutica compatível com os desafios contemporâneos. Curitiba: Juruá, 2011, p. 63-80.
} 
(art. 74, §2º); 6. Direito de participação na fixação da política agrícola (artigo 187 da CF/88); 7. Direito à participação comunitária na gestão democrática e descentralizada da seguridade social, da saúde, assistência social e ensino público (artigos 194, parágrafo único, VII; 198, III; 204, II; e 206, VI da CF/88); 8. Direito de participação na proteção do patrimônio cultural (artigo 216, § $1^{\circ}$ e 216-A, X da CF/88); 9. Direito de participação na defesa do meio ambiente (artigo 225 da CF/88); 10. Direito de participação na assistência à saúde e do adolescente (artigo 227, $\S 1^{\circ}$ da $\mathrm{CF} / 88$ ); 11. Direito de participação na gestão do Fundo de Combate à Pobreza (artigo 82 do ADCT).

No âmbito infraconstitucional também merece destaque, ainda, a edição de uma série de instrumentos legislativos que fomentam a participação popular e o controle social da Administração Pública, dos quais são exemplos: 1. Lei sobre a criação de Organizações Sociais (Lei Federal n. 9.637/1998); 2. Lei sobre a criação de Organizações da Sociedade Civil de Interesse Público (Lei Federal n. 9.790/1999); 3. Estatuto da Criança e do Adolescente e criação dos Conselhos Tutelares (Lei Federal n. 8.069/1990; 4. Lei que regula a participação da comunidade na gestão do Sistema Único de Saúde (SUS) (Lei Federal n. 8.142/1990); 5. Lei Orgânica da Assistência Social (Lei Federal n. 8.742/1993); 6. Lei de Diretrizes e Bases da Educação (Lei Federal n. 9.394/1996); 7. Lei que regulamenta o Fundo de Manutenção e Desenvolvimento da Educação Básica (FUNDEB) e o seu respectivo Conselho (Lei Federal n. 11.494/2007); 8. Lei de Acesso à Informação (Lei Federal n. $12.527 / 2011)$.

Outro relevante dado vem das diversas previsões legislativas espraiadas pelo ordenamento jurídico, que preveem a realização de audiências e consultas públicas sobre os mais variados temas, ${ }^{15}$ dentre as quais merece destaque: 1 . O artigo 39 da Lei Federal n. 8.666/1993 (Lei de Licitações e Contratos), que determina a realização de audiência pública, como fase inicial, nos processos licitatórios de elevados montantes financeiros; 2. Os artigos $9^{\circ}, \S 4^{\circ}$ e 48, parágrafo único, I da Lei Complementar Federal n. 101/2000 (Lei de Responsabilidade Fiscal), que preveem a realização de audiências públicas como instrumento de transparência da gestão fiscal do Poder Público; 3. Os artigos 31 a 34 da Lei Federal n. 9.784/1999 (Lei do Processo Administrativo Federal), que regulam as possibilidades de consultas públicas sobre matérias de interesse geral; 4. Os artigos 40, I, 43, 44 e 45 da Lei 
Federal n. 10.257/2001 (Estatuto da Cidade), que regulam as exigências de audiências públicas para a aprovação do Plano Diretor Municipal, a gestão democrática da cidade e a gestão orçamentária participativa.

No mesmo passo, as experiências havidas em torno do modelo de orçamento participativo $^{16}$ servem de exemplo do potencial de participação nas decisões administrativas que esses mecanismos podem oferecer. Por certo, inclusive por representarem instrumentos novos de participação, muitas vezes aplicados em comunidades ainda carentes de uma série de questões, carentes mesmo de formação política, estes mecanismos acabam não por não atingir todo o seu potencial emancipatório e participativo, podendo sucumbir a apropriações por interesses de grupos políticos e partidários, o que acaba por reduzir ou mesmo aniquilar, em alguns casos, o seu espírito de espaço de efetiva participação democrática e construção social das decisões do Poder Público.

A participação popular da sociedade civil na formulação, acompanhamento da execução e controle das decisões do Poder Público acerca de uma série de políticas públicas, apresenta-se como um dos mais fecundos traços de consolidação de um modelo de Administração Pública democrática. Isso reclama, inclusive, a efetiva ampliação dos canais de diálogo entre os governos e a sociedade civil, assecuratórios da participação social na atividade e na decisão administrativa, pela via instrumental das audiências públicas, consultas públicas, fóruns de debate etc., com o fortalecimento da atuação de comissões e conselhos sociais e populares e a aproximação da sociedade civil ao debate democrático sobre as políticas públicas que impactam na vida da comunidade política.

Sobre a construção de um modelo de Administração Pública democrática e de participação administrativa, Gustavo Justino de OLIVEIRA apresenta três efeitos caracterizados como extremamente positivos: 1. Uma primeira questão refere-se à maior publicidade e transparência na condução dos assuntos de interesse coletivo, com a densificação do princípio da publicidade administrativa (artigo 37, caput da CF/88); 2. Da mesma forma, possibilita aos cidadãos um maior e melhor espaço de informação e conhecimento sobre as diretrizes dos órgãos administrativos, o que enseja tanto a informação

\footnotetext{
${ }^{15}$ Sobre o instituto da audiência pública, consultar: OLIVEIRA, Gustavo Justino de. As audiências públicas e o processo administrativo brasileiro. Revista de Direito Administrativo, Rio de Janeiro, n. 209, p. 153-167, jul./set. 1997.

${ }^{16}$ Sobre a questão da democracia pela via do orçamento participativo no Brasil e também no Estado de Santa Catarina, consultar: AVRITZER, Leonardo; NAVARRO, Zander (Org.). A inovação democrática no Brasil: o orçamento participativo. São Paulo: Cortez, 2003; LÜCHMANN, Lígia Helena Hahn; BORBA, Julian (Org.). Orçamento participativo: análise das experiências desenvolvidas em Santa Catarina. Florianópolis, Insular, 2007.
} 
dos cidadãos, como habilita o órgão administrativo a decidir de forma mais acertada e justa, uma vez que passa a dispor de um maior conhecimento acerca da situação subjacente à decisão administrativa; 3. Há, ainda, outra importante contribuição, no sentido de que esses mecanismos de participação criam espaços de efetiva negociação, em que as decisões administrativas passam a ser tomadas a partir da harmônica ponderação entre os interesses envolvidos, na ótica da reciprocidade de concessões (OLIVEIRA, 2009, p. 6802-6821).

$\mathrm{Na}$ mesma linha, sobre o fenômeno da democratização da atividade administrativa e seu fator de legitimação na comunidade política, Gustavo BINENBOJM ressalta a "abertura e fomento à participação dos administrados nos processos decisórios da Administração, tanto em defesa de interesses individuais (participação uti singulus), como em nome de interesses gerais da coletividade (participação uti cives)". Esta preocupação crescente com a disciplina e democratização dos procedimentos formativos da vontade administrativa acaba por contribuir para a consecução de três importantes finalidades públicas: 1. Respeito aos direitos do contraditório e ampla defesa dos interessados; 2. Aumento do nível de informação da Administração sobre os reflexos de determinada medida administrativa, sob a ótica dos cidadãos e previamente ao agir administrativo; 3. Alcance de um grau mais elevado de consensualidade e legitimação das decisões administrativas (BINENBOJM, 2008, p. 77).

Em uma relação conjugada e integrada à dimensão da participação popular na formação das decisões administrativas (controle social), substancialmente ampliada e densificada a partir do princípio estruturante do Estado democrático de direito, há também um enorme fomento da relevância normativa do princípio da eficiência administrativa. ${ }^{17} \mathrm{O}$ Estado democrático de direito impõe, como nenhum outro, o dever de eficiência ao Poder Público, sobretudo com vistas à efetiva promoção dos direitos fundamentais sociais, pela via da adequada prestação de serviços públicos e racionalização da atividade administrativa.

O princípio da eficiência administrativa somente foi alçado à condição de princípio constitucional expresso a partir da Emenda Constitucional n. 19, de 04 de junho de 1998, envolto no movimento de reforma administrativa do Estado brasileiro e normatização de

\footnotetext{
17 Sobre o princípio constitucional da eficiência administrativa, consultar: BATISTA JÚNIOR, Onofre Alves. Princípio constitucional da eficiência administrativa. 2. ed. Belo Horizonte: Fórum, 2012; GABARDO, Emerson. Eficiência e legitimidade do Estado: uma análise das estruturas simbólicas do direito político. Barueri: Manole, 2003; MARCELLINO JR., Julio Cesar. Princípio constitucional da eficiência administrativa: (des)encontros entre economia e direito. Florianópolis: Habitus, 2009.
} 
instrumentos para um modelo gerencial de Administração Pública, ${ }^{18}$ positivado no artigo 37, caput da Constituição Federal. Nada obstante, não há maiores dificuldades em reconhecer que o dever de eficiência sempre esteve presente na atual ordem constitucional do país, o que pode ser extraído, por exemplo, da atribuição de controle da economicidade pelos sistemas de controle externo e interno de cada Poder (artigo 70, caput da $\mathrm{CF} / 88$ ); da avaliação de resultados quanto à eficácia e eficiência da gestão orçamentária, financeira e patrimonial da Administração Pública (artigo 74, II da CF/88); da previsão de que lei deverá dispor sobre a organização e o funcionamento da segurança pública, de maneira a garantir a eficiência de suas atividades (artigo $144, \S 7^{\circ} \mathrm{da} \mathrm{CF} / 88$ ).

Ao analisar o princípio da eficiência administrativa, Paulo MODESTO (2000) sintetiza que a obrigação de atuação eficiente impõe: 1. Ação idônea (eficaz); 2. Ação econômica (otimizada); 3. Ação satisfatória (dotada de qualidade). A partir de tais parâmetros, define eficiência administrativa como a exigência jurídica, imposta à Administração Pública e àqueles que lhe façam as vezes "ou simplesmente recebem recursos públicos vinculados de subvenção ou fomento, de atuação idônea, econômica e satisfatória na realização das finalidades públicas que lhe forem confiadas por lei ou por ato ou contrato de direito público".

Com base nesses parâmetros, não parece adequado considerar o princípio da eficiência administrativa, como dever do agir administrativo, a partir de uma relação necessária, constitutiva ou até impositiva de um modelo gerencial (ou até, como se possa pensar, uma faceta neoliberal) de Administração Pública, ainda que a aproximação não seja de todo vazia. $\mathrm{Na}$ verdade, o dever instrumental de eficiência, tanto na perspectiva da racionalidade e otimização no uso dos meios e recursos disponíveis, como no aspecto da melhor satisfação possível dos resultados esperados e exigidos do agir administrativo (política e normativamente), apresenta-se como autêntica expressão normativa de densificação do próprio Estado democrático de direito, elemento instrumental fundamental à otimizada prossecução dos direitos fundamentais individuais e (sobretudo) sociais assegurados pela ordem constitucional, fator mesmo de legitimidade da atuação estatal. ${ }^{19}$

\footnotetext{
${ }^{18}$ Sobre a reforma administrativa no Brasil e o modelo de Administração gerencial, consultar: FIGUEIREDO, Cláudio Eduardo Regis de. Administração gerencial \& a reforma administrativa no Brasil. 1. ed. 7. tir. Curitiba: Juruá, 2008, p. 65-182.

${ }^{19}$ Sobre as dimensões da legitimidade, da finalidade, da eficiência administrativa e da consecução de resultados do agir da Administração Pública, a partir de uma perspectiva pós-moderna de Direito Administrativo e sua relação com o Estado democrático de direito e a prossecução dos direitos fundamentais, consultar: MOREIRA NETO, Diogo de Figueiredo. Quatro paradigmas do Direito Administrativo pós-moderno: legitimidade, finalidade, eficiência, resultados. Belo Horizonte: Fórum, 2008.
} 


\section{CONCLUSÃO}

Os firmes ventos de constitucionalização do Direito Administrativo exigem o abandono da lógica tradicional, quase sempre informada por um epicentro normativo e conceitual de dimensão estatal. No salão nobre da juridicidade administrativa abre-se agora a mesa de honra para a perspectiva axiológico-normativa da dignidade humana, do princípio republicano e do Estado democrático de direito, este último objeto central de debate no presente ensaio.

Com efeito, importa reconhecer que a própria finalidade precípua (compromisso genético) da Administração Pública está em fazer-se prisioneira cativa da promoção e defesa dos direitos fundamentais, base não só para os fins da atividade administrativa, mas também fundamento de legitimidade à própria existência estatal.

Em síntese, a ordem constitucional permite defender, com solidez conceitual, normativa, lógica e axiológica, na linha proposta por Juarez FREITAS, a existência de um autêntico direito fundamental à boa administração, a impor ao Estado não somente uma adequada gestão dos meios e recursos públicos no cumprimento das suas obrigações constitucionais, mas também e principalmente uma gestão aberta, um modelo de governança plural e democrática. Nesta quadra, cabe reconhecer a existência de um genuíno "direito fundamental à administração pública eficiente e eficaz, proporcional cumpridora de seus deveres, com transparência, motivação, imparcialidade e respeito à moralidade, à participação social e à plena responsabilidade por suas condutas omissivas e comissivas" (FREITAS, 2007, p. 20).

A exigência do cumprimento de padrões otimizados de eficiência na gestão administrativa, na prestação de serviços públicos de qualidade e na máxima ampliação e satisfação dos direitos fundamentais individuais e sociais constitui-se em decorrência direta e instrumento normativo de concretização do Estado democrático de direito. $\mathrm{O}$ direito fundamental dos cidadãos à boa administração determina a construção de um tipo de Administração Pública que seja, a um só tempo, transparente e dialógica nas suas ações, mas também proba e imparcial nas suas relações. Um modelo capaz de fundar o agir administrativo a partir de uma dimensão ponderada de princípios, com vistas à otimizada e eficiente concretização desse complexo sistema axiológico de regras e princípios 
constitucionais, em especial aqueles veiculadores de direitos fundamentais individuais e sociais.

\section{REFERÊNCIAS}

AVRITZER, Leonardo; NAVARRO, Zander (Org.). A inovação democrática no Brasil: o orçamento participativo. São Paulo: Cortez, 2003.

BARROSO, Luís Roberto. A constitucionalização do direito e suas repercussões no âmbito administrativo. In: ARAGÃO, Alexandre dos Santos; MARQUES NETO, Floriano de Azevedo (Coord.). Direito Administrativo e seus novos paradigmas. Belo Horizonte: Fórum, 2008, p. 31-63.

BATISTA JÚNIOR, Onofre Alves. Princípio constitucional da eficiência administrativa. 2. ed. Belo Horizonte: Fórum, 2012.

BINENBOJM, Gustavo. Uma teoria do Direito Administrativo: direitos fundamentais, democracia e constitucionalização. 2. ed. São Paulo: Renovar, 2008.

BOBBIO, Norberto. $O$ futuro da democracia: uma defesa das regras do jogo. Tradução de Marco Aurélio Nogueira. Rio de Janeiro: Paz e Terra, 1986.

BORGE, Felipe Dezorzi. Ativismo jurídico: expressão do acesso à Justiça e da cidadania ativa. Jus Navigandi, Teresina, ano 14, n. 2317, nov. 2009. Disponível em: 〈http://jus.com.br/artigos/13794〉. Acesso em: 08 set. 2016.

BONAVIDES, Paulo. Teoria constitucional da democracia participativa: por um Direito Constitucional de luta e resistência, por uma nova hermenêutica, por uma repolitização da legitimidade. 2. ed. São Paulo: Malheiros, 2003.

CANOTILHO, José Joaquim Gomes. Direito Constitucional e teoria da Constituição. 7. ed. Coimbra: Almedina, 2003. 
CRISTÓVAM, José Sérgio da Silva. Administração Pública democrática e supremacia do interesse público: novo regime jurídico-administrativo e seus princípios constitucionais estruturantes. Curitiba: Juruá, 2015.

CUNNINGHAM, Frank. Teorias da democracia: uma introdução crítica. Tradução de Delamar José Volpato Dutra. Porto Alegre: Artmed, 2009.

DAHL, Robert A. Sobre a democracia. Brasília: UnB, 2001.

FIALHO, Andrea Cristina de Souza. A reforma do Estado e os novos paradigmas do controle da Administração Pública. In: SILVA, Maria Teresinha Pereira; ZANOTELLI, Maurício (Coord.).

Direito e Administração Pública: por uma hermenêutica compatível com os desafios contemporâneos. Curitiba: Juruá, 2011, p. 63-80.

FIGUEIREDO, Cláudio Eduardo Regis de. Administração gerencial \& a reforma administrativa no Brasil. 1. ed. 7. tir. Curitiba: Juruá, 2008.

GABARDO, Emerson. Eficiência e legitimidade do Estado: uma análise das estruturas simbólicas do direito político. Barueri: Manole, 2003.

GARAPON, Antoine. O Juiz e a Democracia: o guardião de promessas. Tradução de Maria Luiza de Carvalho. 2. ed. Rio de Janeiro: Revan, 1999.

GARCIA DE ENTERRIA, Eduardo. Democracia, jueces y control de la Administración. 4. ed. Madrid: Civitas, 1998.

HABERMAS, Jürgen. Direito e democracia: entre facticidade e validade. Tradução de Flávio Beno Siebeneichler. v. I e II. Rio de janeiro: Tempo Brasileiro, 1997.

LEITE, Gisele. Considerações sobre ativismo judicial, constitucionalismo e democracia. Jus Navigandi, Teresina, ano 19, jan. 2014. Disponível em: <http://jus.com.br/artigos/26337>. Acesso em: 08 set. 2016.

LÜCHMANN, Lígia Helena Hahn; BORBA, Julian (Org.). Orçamento participativo: análise das experiências desenvolvidas em Santa Catarina. Florianópolis, Insular, 2007. 
MARCELLINO JR., Julio Cesar. Princípio constitucional da eficiência administrativa: (des)encontros entre economia e direito. Florianópolis: Habitus, 2009.

MEZZAROBA, Orides. A reforma política e a crise de representatividade do sistema partidário brasileiro. Sequência: Estudos Jurídicos e Políticos, Florianópolis, v. 27, n. 53, p. 95-112, dez. 2006.

MIRANDA, Jorge. Manual de Direito Constitucional: direitos fundamentais. t. IV. 5. ed. Coimbra: Coimbra Editora, 2012.

MOREIRA NETO, Diogo de Figueiredo. Quatro paradigmas do Direito Administrativo pósmoderno: legitimidade, finalidade, eficiência, resultados. Belo Horizonte: Fórum, 2008.

NASPOLINI, Samuel Dal-Farra. Pluralismo político: subsídios para análise dos sistemas político e eleitoral brasileiros em face da CF/88. Curitiba: Juruá, 2006.

OLIVEIRA, Gustavo Justino de. As audiências públicas e o processo administrativo brasileiro. Revista de Direito Administrativo, Rio de Janeiro, n. 209, p. 153-167, jul./set. 1997.

SANTOS, Milton. Por uma outra globalização: do pensamento único à consciência universal. 5. ed. Rio de Janeiro: Record, 2001.

SILVA, Felipe Gonçalves. Iris Young, Nancy Fraser e Seyla Benhabib: uma disputa entre modelos críticos. In: NOBRE, Marcos (Org.). Curso livre de teoria crítica. Campinas: Papirus, 2008, p. 199226.

TAVARES, André Ramos; BUCK, Pedro. Direitos fundamentais e democracia: complementaridade/contrariedade. In: CLÈVE, Clèmerson Merlin; SARLET, Ingo Wolfgang; PAGLIARINI, Alexandre Coutinho (Org.). Direitos humanos e democracia. Rio de Janeiro: Forense, 2007, p. 169-186. 